Review

\title{
Henipavirus Infections: Lessons from Animal Models
}

\section{Kévin P. Dhondt ${ }^{1}$ and Branka Horvat ${ }^{2, *}$}

1 International Center for Infectiology Research, INSERM U1111, CNRS UMR5308, Ecole Normale Supérieure de Lyon, University of Lyon 1, 21 Avenue T. Garnier, Lyon 69007, France;

E-Mail: kevin.dhondt@inserm.fr

2 International Center for Infectiology Research, INSERM U1111, CNRS UMR5308, Ecole Normale Supérieure de Lyon, University of Lyon 1, 21 Avenue T. Garnier, Lyon 69007, France; E-Mail: branka.horvat@inserm.fr

* Author to whom correspondence should be addressed; E-Mail: branka.horvat@inserm.fr; Tel.: +33-43728-2392; Fax: +33-43728-2391.

Received: 6 March 2013; in revised form: 2 April 2013 / Accepted: 4 April 2013 /

Published: 9 April 2013

\begin{abstract}
The Henipavirus genus contains two highly lethal viruses, the Hendra and Nipah viruses and one, recently discovered, apparently nonpathogenic member; Cedar virus. These three, negative-sense single-stranded RNA viruses, are hosted by fruit bats and use EphrinB2 receptors for entry into cells. The Hendra and Nipah viruses are zoonotic pathogens that emerged in the middle of 90 s and have caused severe, and often fatal, neurologic and/or respiratory diseases in both humans and different animals; including spillover into equine and porcine species. Development of relevant models is critical for a better understanding of viral pathogenesis, generating new diagnostic tools, and assessing anti-viral therapeutics and vaccines. This review summarizes available data on several animal models where natural and/or experimental infection has been demonstrated; including pteroid bats, horses, pigs, cats, hamsters, guinea pigs, ferrets, and nonhuman primates. It recapitulates the principal features of viral pathogenesis in these animals and current knowledge on anti-viral immune responses. Lastly it describes the recently characterized murine animal model, which provides the possibility to use numerous and powerful tools available for mice to further decipher henipaviruses immunopathogenesis, prophylaxis, and treatment. The utility of different models to analyze important aspects of henipaviruses-induced disease in humans, potential routes of transmission, and therapeutic approaches are equally discussed.
\end{abstract}


Keywords: emergent infections; zoonosis; pathogenesis; animal models

\section{Introduction}

The Hendra and Nipah viruses $(\mathrm{HeV}$ and $\mathrm{NiV})$ are recently emerged zoonotic viruses responsible for outbreaks of respiratory and neurological disease in livestock and humans. Both are negative-sense single stranded RNA viruses and belong to the Henipavirus genus within the Paramyxoviridae family [1]. Very recently, a third member, the Cedar virus, joined the Henipavirus genus. While $\mathrm{HeV}$ and NiV infection are known to cause very high mortality rates, ranging between 40 and 100\% in both humans and animals [2,3], the Cedar virus seems to be nonpathogenic. Henipaviruses genomes are among the largest of the Paramyxoviridae family, exceeding $18 \mathrm{~kb}$, with sequence homology between $\mathrm{HeV}$ and NiV ranging from 78 to $92 \%$, and between $\mathrm{HeV}$ and Cedar virus from $28 \%$ to $58 \%$ [4]. Henipaviruses virions consist of six structural proteins. The genomic RNA is enclosed by nucleocapsid proteins, which together with phosphoprotein and RNA polymerase large protein forms the transcriptase complex. The viral envelope is formed by matrix proteins associated to a lipid bi-layer and two surface glycoproteins, glycoprotein and fusion protein, which allow, respectively, viral attachment and entry into the host cell. As in other paramyxoviruses, $\mathrm{P}$ gene encodes for non-structural proteins: $\mathrm{C}$ protein from the alternative open reading frame and $\mathrm{W}$ and $\mathrm{V}$ proteins, following RNA transcriptional editing, although this editing ability of viral polymerase seems to be absent in the Cedar virus [4].

$\mathrm{HeV}$ was identified as the causative agent of an outbreak of acute respiratory disease in humans and thoroughbred horses in Brisbane, Australia in 1994 [5]. Since its first appearance, HeV has re-emerged several times and presents a serious threat to horse livestock in Australia, with sporadic and lethal transmission to humans. NiV was first recognized following a 1998-99 outbreak of severe febrile encephalitis in Malaysia and Singapore [6,7]. Subsequent outbreaks of NiV occurred in India and almost annually in Bangladesh [8-10], where the sequence of Bangladesh isolate of NiV was shown to differ slightly from the Malaysia isolate [11]. Comparison between Malaysia and Bangladesh isolates revealed a nucleotide variation range of $6.32 \%-9.15 \%$ and an amino acid variation range of $1.42 \%-9.87 \%$ [12]. Survivors of acute encephalitis may experience relapse encephalitis years after initial infection and people that get infected asymptomatically may develop a late onset disease [13]. Cases of inter-human transmission of NiV-Bangladesh further extends its potential to cause deadly outbreaks $[14,15]$. Furthermore, the distribution area of henipaviruses and henipa-like viruses ranges outside Australia and Asia. Serological evidence found in African fruit bats [16] suggests the circulation of henipa-like viruses across this continent and new viruses will probably join this genus in the future. The ability to cause serious human and animal diseases which can be transmitted from one individual to another, and the lack of efficient treatment and preventive measures, led to the classification of $\mathrm{HeV}$ and $\mathrm{NiV}$ as biosecurity level 4 (BSL-4) pathogens.

The cellular and molecular basis of high pathogenicity of $\mathrm{HeV}$ and $\mathrm{NiV}$ is still far from being understood. The development of adequate animal models is required for better comprehension of Henipavirus infection and their transmission as well as for the generation of efficient prevention and treatment. As these viruses are zoonotic, there are a number of different animal species susceptible to 
infection. Some of them are natural hosts and their investigation could provide useful information about virus replication, shedding, and transmission. Laboratory animal models were developed to evaluate vaccines and anti-viral treatments. Finally, the relevance of different models for understanding the infection in humans varies among models. This review discusses the major characteristics of animal models used to study $\mathrm{HeV}$ and $\mathrm{NiV}$ infection and summarizes the principal features of viral pathogenesis in the most commonly used models (Table 1).

\section{Fruit Bats}

There is increasing evidence that bats play a major role in the emergence and transmission of new and deadly zoonotic viruses $[62,63]$. Fruit bats (Pteropus species) are putative natural reservoir hosts for a number of viruses, including $\mathrm{NiV}, \mathrm{HeV}$, and the Ebola virus. Although these viruses often cause asymptomatic infections in their natural host, once they cross the species barrier they can become extremely virulent with high mortality rates. Serological studies have shown that the seroprevalence of antibodies to henipaviruses in pteropid bats varies from $10 \%$ to $50 \%$ in numerous countries, including Australia [64,65], Malaysia [66], India [67], Cambodia [68,69], Indonesia [70], and Thailand [71]. Subsequent analysis showed serological evidence for henipaviruses in China [72], Madagascar, Papua New Guinea, and Ghana [73], thus, expanding significantly the known distribution of these viruses. $\mathrm{HeV}$ was initially isolated from uterine fluid and fetal tissue of a Pteropus policephalus and P. alecto [65]. NiV was isolated from urine of P. hypomelanus in Malaysia [74], and P. lylei in Cambodia [69]. Analysis of captive $P$. vampyrus showed high seroprevalence and horizontal transmission of the Nipah virus [75]. Finally, a new member of Henipavirus genus, the Cedar virus, was recently isolated from urine samples from Australian flying foxes [4].

Experimental infection of fruit bats with $\mathrm{HeV}$ and $\mathrm{NiV}$ virus was followed by seroconversion in the majority of animals but showed absence of visible clinical disease, despite the inoculation of rather high viral doses. $\mathrm{HeV}$ infection of grey-headed fruit bats ( $P$. poliocephalus) resulted in vascular lesions, positive immunostaining, and virus isolation [18]. Virus was also recovered from the fetus, confirming that pathogenesis in pregnant animals may result in viral crossing of the placenta, supporting thus the possibility of vertical transmission. However, transmission of $\mathrm{HeV}$ from bats to horses could not be experimentally demonstrated [18]. Experimental subcutaneous NiV infection in grey-headed fruit bats resulted in generation of neutralizing antibodies and histological changes in different tissues. The isolation of the virus was possible from the urine, kidney, and uterus [17]. Oronasal Henipavirus infection of bats gave only occasional seroconversion. Virus isolation was usually not possible, although $\mathrm{HeV}$ was isolated from one P. alecto female in that study [19]. Occasional low-level excretion of henipaviruses in the urine of bats may be sufficient to sustain virus circulation in bat colonies. Nevertheless, the rare and sporadic spillovers seem to require the coincidence of a range of individual and environmental factors. Taken together, these studies demonstrate that fruit bats can carry henipaviruses, without the manifestations of clinical disease or any gross pathology, in contrast to most of other mammalian species. However, the mechanism responsible for the efficient control of viral replication in bats remains to be elucidated. Understanding how bats coexist with viruses has important implications in predicting spillover events from bats to other susceptible species. 
Table 1. Principal characteristics and current utilization of animal models of $\mathrm{NiV}$ (white fields) and $\mathrm{HeV}$ (grey fields) infection. +++ advised model, ++ highly suitable model, + suitable model, +/- better models existing, - model not recommended.

\begin{tabular}{|c|c|c|c|c|c|c|c|c|c|c|c|}
\hline \multirow[b]{2}{*}{ Species } & \multicolumn{2}{|c|}{ Clinical signs } & \multirow[b]{2}{*}{ Gross lesions } & \multirow[b]{2}{*}{ Histology } & \multirow[b]{2}{*}{ Virus found in } & \multicolumn{5}{|c|}{ Utilisation of the model } & \multirow[b]{2}{*}{ References } \\
\hline & Respiratory & Neurological & & & & $\begin{array}{c}\text { Patho- } \\
\text { logy }\end{array}$ & $\begin{array}{l}\text { Immu- } \\
\text { nology }\end{array}$ & $\begin{array}{c}\text { Drugs } \\
\text { assess- } \\
\text { ment }\end{array}$ & $\begin{array}{c}\text { Vaccine } \\
\text { assess- } \\
\text { ment }\end{array}$ & $\begin{array}{l}\text { Epide- } \\
\text { miology }\end{array}$ & \\
\hline \multirow[t]{2}{*}{ Fruit bat } & - & - & $\begin{array}{l}\text { petechial hemorrhages } \\
\text { on urine bladder wall }\end{array}$ & $\begin{array}{l}\text { granulomatous hepatitis, } \\
\text { inflammation of bladder } \\
\text { epithelium, vasculitis, } \\
\text { testicular degeneration }\end{array}$ & $\begin{array}{l}\text { kidney, urine, } \\
\text { uterus }\end{array}$ & \multirow[t]{2}{*}{ - } & \multirow[t]{2}{*}{+} & \multirow[t]{2}{*}{ - } & \multirow[t]{2}{*}{ - } & \multirow[t]{2}{*}{+++} & [17] \\
\hline & - & - & - & $\begin{array}{l}\text { necrosis and hemorrhage of } \\
\text { the adrenal gland }\end{array}$ & urine, rectal swab & & & & & & {$[18,19]$} \\
\hline \multirow[b]{2}{*}{ Pig } & $\begin{array}{c}\text { severe non- } \\
\text { productive cough }\end{array}$ & $\begin{array}{l}\text { shivering, } \\
\text { seizures }\end{array}$ & $\begin{array}{c}\text { lymph nodes } \\
\text { hyperplasia, } \\
\text { congestion, edema }\end{array}$ & $\begin{array}{l}\text { hyperplasia of BALT, } \\
\text { meningitis, encephalitis }\end{array}$ & $\begin{array}{l}\text { lymphoid organs, } \\
\text { CNS, lung }\end{array}$ & \multirow[b]{2}{*}{+} & \multirow[b]{2}{*}{+} & \multirow{2}{*}{$\begin{array}{c}++ \text { (vet. } \\
\text { use) }\end{array}$} & \multirow{2}{*}{$\begin{array}{c}++ \text { (vet. } \\
\text { use) }\end{array}$} & \multirow[b]{2}{*}{+++} & [20-24] \\
\hline & $\begin{array}{l}\text { cough, } \\
\text { respiratory } \\
\text { distress }\end{array}$ & $\begin{array}{l}\text { incoordination } \\
\text { (transient) }\end{array}$ & $\begin{array}{l}\text { congestion, } \\
\text { hemorrhages }\end{array}$ & $\begin{array}{c}\text { syncytial cells in nasal } \\
\text { turbinates and bronchiolar } \\
\text { epithelium }\end{array}$ & $\begin{array}{l}\text { tonsils, BALF, } \\
\text { lung, nasal } \\
\text { turbinates, lymph } \\
\text { nodes, swabs } \\
\end{array}$ & & & & & & [25] \\
\hline \multirow[b]{2}{*}{ Horse } & - & - & - & meningitis & - & \multirow[b]{2}{*}{+} & \multirow[b]{2}{*}{ - } & \multirow[b]{2}{*}{$\begin{array}{c}++ \text { (vet. } \\
\text { use) }\end{array}$} & \multirow[b]{2}{*}{$\begin{array}{c}++(\text { vet. } \\
\text { use) }\end{array}$} & \multirow[b]{2}{*}{+++} & [26] \\
\hline & $\begin{array}{l}\text { increased } \\
\text { respiratory rate, } \\
\text { frothy nasal } \\
\text { discharge }\end{array}$ & $\begin{array}{l}\text { ataxia, head } \\
\text { pressing, } \\
\text { myoclonic } \\
\text { twitches }\end{array}$ & $\begin{array}{l}\text { congestion, edema, } \\
\text { hemorrhages in lung }\end{array}$ & $\begin{array}{l}\text { interstitial pneumonia, } \\
\text { vasculitis, syncytia in } \\
\text { endothelium }\end{array}$ & $\begin{array}{c}\text { brain, lung, } \\
\text { lymphoid organs, } \\
\text { kidney, bronchial } \\
\text { and oral swabs, } \\
\text { urine }\end{array}$ & & & & & & {$[5,18,27,28]$} \\
\hline
\end{tabular}


Table 1. Cont.

\begin{tabular}{|c|c|c|c|c|c|c|c|c|c|c|c|}
\hline \multirow[b]{2}{*}{ Species } & \multicolumn{2}{|c|}{ Clinical signs } & \multirow[b]{2}{*}{ Gross lesions } & \multirow[b]{2}{*}{ Histology } & \multirow[b]{2}{*}{ Virus found in } & \multicolumn{5}{|c|}{ Utilisation of the model } & \multirow[b]{2}{*}{ References } \\
\hline & Respiratory & Neurological & & & & $\begin{array}{c}\text { Patho- } \\
\text { logy }\end{array}$ & $\begin{array}{l}\text { Immu- } \\
\text { nology }\end{array}$ & $\begin{array}{c}\text { Drugs } \\
\text { assess- } \\
\text { ment }\end{array}$ & $\begin{array}{c}\text { Vaccine } \\
\text { assess- } \\
\text { ment }\end{array}$ & $\begin{array}{l}\text { Epide- } \\
\text { miology }\end{array}$ & \\
\hline \multirow{2}{*}{ Cat } & $\begin{array}{l}\text { tachypnea, } \\
\text { dyspnea }\end{array}$ & - & $\begin{array}{c}\text { congestion, edema, } \\
\text { hemorrhages, enlarged } \\
\text { lymph nodes }\end{array}$ & $\begin{array}{c}\text { acute bronchiolitis, } \\
\text { necrotizing alveolitis, } \\
\text { vasculitis, endothelial } \\
\text { syncytia }\end{array}$ & $\begin{array}{l}\text { lung, spleen, } \\
\text { kidney, lymph } \\
\text { nodes }\end{array}$ & \multirow{2}{*}{$+/-$} & \multirow{2}{*}{-} & \multirow{2}{*}{+} & \multirow{2}{*}{++} & & {$[21,29-31]$} \\
\hline & $\begin{array}{l}\text { dyspnea, open } \\
\text { mouth breathing }\end{array}$ & - & $\begin{array}{l}\text { hydrothorax, } \\
\text { congestion, edema, } \\
\text { hemorrhages }\end{array}$ & $\begin{array}{c}\text { inflammation in lung, } \\
\text { alveolar wall necrosis, } \\
\text { vasculitis, endothelial } \\
\text { syncytia }\end{array}$ & $\begin{array}{l}\text { lung, spleen, } \\
\text { lymph nodes }\end{array}$ & & & & & & {$[18,32-34]$} \\
\hline \multirow[b]{2}{*}{ Ferret } & $\begin{array}{c}\text { dyspnea, cough, } \\
\text { serous nasal } \\
\text { discharge }\end{array}$ & $\begin{array}{l}\text { depression, } \\
\text { tremors, } \\
\text { myoclonus, } \\
\text { hind limb } \\
\text { paresis }\end{array}$ & \multirow{2}{*}{$\begin{array}{l}\text { edema, hemorrhages, } \\
\text { enlarged lymph nodes }\end{array}$} & \multirow{2}{*}{$\begin{array}{l}\text { necrotizing alveolitis, } \\
\text { glomerular necrosis, } \\
\text { vasculitis, endothelial } \\
\text { syncytia, meningitis }\end{array}$} & $\begin{array}{c}\text { brain, lung, } \\
\text { lymphoid organs, } \\
\text { adrenal, kidney, } \\
\text { testes, uterus, } \\
\text { liver, pharyngeal } \\
\text { and rectal swabs }\end{array}$ & \multirow[b]{2}{*}{+} & \multirow[b]{2}{*}{-} & \multirow[b]{2}{*}{++} & \multirow[b]{2}{*}{++} & \multirow[b]{2}{*}{. } & [35-38] \\
\hline & - & $\begin{array}{l}\text { depression, } \\
\text { tremors }\end{array}$ & & & $\begin{array}{l}\text { lung, lymphoid } \\
\text { organs, adrenal, } \\
\text { meninges, } \\
\text { kidney, liver, } \\
\text { testes, oral and } \\
\text { rectal swabs, } \\
\text { blood, urine }\end{array}$ & & & & & & [39] \\
\hline
\end{tabular}


Table 1. Cont.

\begin{tabular}{|c|c|c|c|c|c|c|c|c|c|c|c|}
\hline \multirow[b]{2}{*}{ Species } & \multicolumn{2}{|c|}{ Clinical signs } & \multirow[b]{2}{*}{ Gross lesions } & \multirow[b]{2}{*}{ Histology } & \multirow[b]{2}{*}{ Virus found in } & \multicolumn{5}{|c|}{ Utilisation of the model } & \multirow[b]{2}{*}{ References } \\
\hline & Respiratory & Neurological & & & & $\begin{array}{c}\text { Patho- } \\
\text { logy }\end{array}$ & $\begin{array}{l}\text { Immu- } \\
\text { nology }\end{array}$ & $\begin{array}{c}\text { Drugs } \\
\text { assess- } \\
\text { ment }\end{array}$ & $\begin{array}{c}\text { Vaccine } \\
\text { assess- } \\
\text { ment }\end{array}$ & $\begin{array}{l}\text { Epide- } \\
\text { miology }\end{array}$ & \\
\hline $\begin{array}{l}\text { Squirrel } \\
\text { Monkey }\end{array}$ & $\begin{array}{l}\text { dyspnea, } \\
\text { tachypnea }\end{array}$ & $\begin{array}{l}\text { ataxia, coma, } \\
\text { seizures }\end{array}$ & not reported & $\begin{array}{l}\text { pulmonar inflammation, } \\
\text { mild vasculitis }\end{array}$ & $\begin{array}{l}\text { lung, brain, } \\
\text { kidney, spleen }\end{array}$ & + & + & $+/-$ & $+/-$ & - & [40] \\
\hline \multirow{2}{*}{$\begin{array}{l}\text { African } \\
\text { Green } \\
\text { Monkey }\end{array}$} & $\begin{array}{l}\text { severe dyspnea, } \\
\text { open-mouth } \\
\text { breathing, } \\
\text { serosanguineous } \\
\text { nasal discharge }\end{array}$ & $\begin{array}{c}\text { muscle } \\
\text { twitches, } \\
\text { behavioral } \\
\text { changes, loss of } \\
\text { balance }\end{array}$ & $\begin{array}{c}\text { pleural effusion, } \\
\text { congestion and } \\
\text { hemorrhage in lungs, } \\
\text { hemorrhages on } \\
\text { mucosal surface of } \\
\text { urinary bladder, } \\
\text { edema and } \\
\text { hemorrhages of the } \\
\text { meninges }\end{array}$ & $\begin{array}{c}\text { endothelial syncytial cells, } \\
\text { vasculitis, meningitis, } \\
\text { inflammation, fibrinoid } \\
\text { necrosis }\end{array}$ & $\begin{array}{l}\text { liver, spleen, } \\
\text { kidney, adrenal } \\
\text { gland, lung, } \\
\text { lymph nodes, } \\
\text { pancreas, sex } \\
\text { organs, urine, } \\
\text { nasal swabs }\end{array}$ & \multirow{2}{*}{ +++ } & \multirow{2}{*}{+} & \multirow{2}{*}{+++} & \multirow{2}{*}{+++} & \multirow{2}{*}{-} & {$[41,42]$} \\
\hline & $\begin{array}{l}\text { nasal discharge, } \\
\text { labored breathing }\end{array}$ & $\begin{array}{l}\text { muscle } \\
\text { twitches, } \\
\text { seizures }\end{array}$ & $\begin{array}{c}\text { pulmonary } \\
\text { consolidation, } \\
\text { congestion of lungs, } \\
\text { enlarged lymph nodes, } \\
\text { congested liver, } \\
\text { inflammation of } \\
\text { gastrointestinal tract, } \\
\text { congestion in the brain }\end{array}$ & $\begin{array}{l}\text { alveolar hemorrhages, } \\
\text { pulmonary edema and } \\
\text { inflammation, alveolitis, } \\
\text { fibrinoid necrosis, } \\
\text { vasculitis, meningitis }\end{array}$ & $\begin{array}{l}\text { lung, lymph } \\
\text { nodes, heart, } \\
\text { liver, spleen, } \\
\text { kidney, adrenal } \\
\text { gland, brain, } \\
\text { urinary bladder, } \\
\text { sex organs }\end{array}$ & & & & & & {$[43,44]$} \\
\hline
\end{tabular}


Table 1. Cont.

\begin{tabular}{|c|c|c|c|c|c|c|c|c|c|c|c|}
\hline \multirow[b]{2}{*}{ Species } & \multicolumn{2}{|c|}{ Clinical signs } & \multirow[b]{2}{*}{ Gross lesions } & \multirow[b]{2}{*}{ Histology } & \multirow[b]{2}{*}{ Virus found in } & \multicolumn{5}{|c|}{ Utilisation of the model } & \multirow[b]{2}{*}{ References } \\
\hline & Respiratory & Neurological & & & & $\begin{array}{c}\text { Patho- } \\
\text { logy }\end{array}$ & $\begin{array}{l}\text { Immu- } \\
\text { nology }\end{array}$ & $\begin{array}{c}\text { Drugs } \\
\text { assess- } \\
\text { ment }\end{array}$ & $\begin{array}{c}\text { Vaccine } \\
\text { assess- } \\
\text { ment }\end{array}$ & $\begin{array}{l}\text { Epide- } \\
\text { miology }\end{array}$ & \\
\hline \multirow[t]{2}{*}{$\begin{array}{l}\text { IFNAR } \\
\text { KO mouse }\end{array}$} & - & $\begin{array}{c}\text { behavioral } \\
\text { troubles, ataxia, }\end{array}$ & $\begin{array}{c}\text { brain and lung } \\
\text { congestion, edema of } \\
\text { bladder wall, } \\
\text { hemorrhages, necrosis } \\
\text { in liver and kidney }\end{array}$ & $\begin{array}{l}\text { vasculitis, inflammation, } \\
\text { meningitis, encephalitis, } \\
\text { necrotizing alveolitis }\end{array}$ & $\begin{array}{l}\text { brain, lung, } \\
\text { spleen, liver }\end{array}$ & \multirow[t]{2}{*}{+} & \multirow[t]{2}{*}{ +++ } & \multirow[t]{2}{*}{+++} & \multirow[t]{2}{*}{+} & \multirow[t]{2}{*}{ - } & [45] \\
\hline & - & & $\begin{array}{l}\text { brain and lung } \\
\text { congestion, } \\
\text { hemorrhages }\end{array}$ & $\begin{array}{l}\text { vasculitis, meningitis, } \\
\text { encephalitis, gliosis, } \\
\text { necrotizing alveolitis }\end{array}$ & $\begin{array}{l}\text { brain, lung, } \\
\text { spleen, liver }\end{array}$ & & & & & & [45] \\
\hline \multirow{2}{*}{$\begin{array}{l}\text { Aged } \\
\text { mouse }\end{array}$} & - & - & - & - & - & \multirow[b]{2}{*}{$+/-$} & \multirow[b]{2}{*}{+} & \multirow[b]{2}{*}{+} & & & - \\
\hline & - & $\begin{array}{c}\text { ataxia, muscle } \\
\text { tremors }\end{array}$ & - & encephalitis, meningitis & $\begin{array}{l}\text { brain, transiently } \\
\text { in lung }\end{array}$ & & & & & & [46] \\
\hline Hamster & $\begin{array}{c}\text { labored } \\
\text { breathing, } \\
\text { serosanguineous } \\
\text { nasal exudates }\end{array}$ & $\begin{array}{l}\text { imbalance, } \\
\text { muscle } \\
\text { twitching, } \\
\text { tremor, limb } \\
\text { paralysis }\end{array}$ & $\begin{array}{c}\text { edema, hemorrhages, } \\
\text { congestion }\end{array}$ & $\begin{array}{l}\text { vasculitis, meningitis, } \\
\text { encephalitis, endothelial } \\
\text { syncytia }\end{array}$ & $\begin{array}{c}\text { lung, nasal } \\
\text { epithelium, CNS, } \\
\text { heart, liver, } \\
\text { spleen, kidney, } \\
\text { bladder, urine }\end{array}$ & +++ & $+/-$ & ++ & ++ & + & [47-58] \\
\hline
\end{tabular}


Table 1. Cont.

\begin{tabular}{|c|c|c|c|c|c|c|c|c|c|c|c|}
\hline \multirow[b]{2}{*}{ Species } & \multicolumn{2}{|c|}{ Clinical signs } & \multirow[b]{2}{*}{ Gross lesions } & \multirow[b]{2}{*}{ Histology } & \multirow[b]{2}{*}{ Virus found in } & \multicolumn{5}{|c|}{ Utilisation of the model } & \multirow[b]{2}{*}{ References } \\
\hline & Respiratory & Neurological & & & & $\begin{array}{c}\text { Patho- } \\
\text { logy }\end{array}$ & $\begin{array}{l}\text { Immu- } \\
\text { nology }\end{array}$ & $\begin{array}{c}\text { Drugs } \\
\text { assess- } \\
\text { ment }\end{array}$ & $\begin{array}{c}\text { Vaccine } \\
\text { assess- } \\
\text { ment }\end{array}$ & $\begin{array}{l}\text { Epide- } \\
\text { miology }\end{array}$ & \\
\hline Hamster & $\begin{array}{l}\text { acute respiratory } \\
\text { distress, } \\
\text { serosanguineous } \\
\text { nasal discharge }\end{array}$ & $\begin{array}{c}\text { imbalance, } \\
\text { ataxia, muscle } \\
\text { twitching, limb } \\
\text { paralysis }\end{array}$ & $\begin{array}{l}\text { inflammation and } \\
\text { edema of the lungs }\end{array}$ & $\begin{array}{l}\text { inflammation, alveolitis, } \\
\text { necrotizing vasculitis, } \\
\text { meningitis, encephalitis, } \\
\text { hemorhage in the brain, } \\
\text { neuronal necrosis, gliosis, } \\
\text { endothelial syncytial cells }\end{array}$ & $\begin{array}{l}\text { spleen, kidney, } \\
\text { heart, lung, brain, } \\
\text { liver }\end{array}$ & & & & & & $\begin{array}{c}{[48,56,58,5} \\
9]\end{array}$ \\
\hline \multirow[t]{2}{*}{$\begin{array}{l}\text { Guinea } \\
\text { pig }\end{array}$} & - & $\begin{array}{l}\text { mild behavioral } \\
\text { changes, ataxia }\end{array}$ & mesenteric edema & $\begin{array}{l}\text { vasculitis, lymphoid } \\
\text { depletion, endothelial } \\
\text { syncytia with fibrinoid } \\
\text { necrosis, edema, } \\
\text { hemorrhage and ulceration } \\
\text { of the urinary bladder, } \\
\text { meningitis }\end{array}$ & $\begin{array}{l}\text { heart, kidney, } \\
\text { lymph nodes, } \\
\text { uterus }\end{array}$ & \multirow[t]{2}{*}{$-/+$} & \multirow[t]{2}{*}{-} & \multirow[t]{2}{*}{ - } & \multirow[t]{2}{*}{ - } & \multirow[t]{2}{*}{ - } & [17] \\
\hline & - & head tilt & $\begin{array}{c}\text { congestion, cyanosis, } \\
\text { edema }\end{array}$ & $\begin{array}{l}\text { pulmonar fibrinoid } \\
\text { necrosis, vasculitis, } \\
\text { endothelial syncytia, } \\
\text { encephalitis }\end{array}$ & $\begin{array}{l}\text { brain, kidney, } \\
\text { urine, uterus, } \\
\text { placenta }\end{array}$ & & & & & & {$[34,60,61]$} \\
\hline
\end{tabular}




\section{Farm and Domestic Animals}

Despite the poor ability of most Paramyxoviridae to cross species-barriers, henipaviruses are able to infect a broad range of mammalian species. The susceptibility of several mammalian species to natural infection with $\mathrm{NiV}$ and $\mathrm{HeV}$ is mainly responsible for their emergence in Southeast Asia and re-emergence each year in Australia and Bangladesh. This observation may be explained by the high conservation of the viral entry receptors, Ephrin (EFN) B2 and B3, amongst mammalian species. Indeed, protein sequence analysis revealed that identity between human and horse, pig, cat, dog, Pteropus bat, and mouse EFN B2 and B3 ranges from 95\% to 98\% [76]. Contrarily to $\mathrm{NiV}$ and $\mathrm{HeV}$ that can use both EFN B2 and B3 receptors [77], the Cedar virus was shown to use EFN B2 receptor only [4].

Farm and domestic animals often play the role of intermediate hosts between the wild reservoir and the human population. Rapidly, after viral emergence, pigs and horses were found to be amplifying secondary hosts, respectively for Malaysia NiV strain and $\mathrm{HeV}$. Yet, looking for secondary reservoirs a broad range of animal species were serologically tested. Birds [9,78], peri-domestic and domestic rodents $[9,66,78,79]$, wild boars, and insectivorous bats [66] tested negative. Both cats and dogs were found to be susceptible to NiV infection even if there were only two field cases for dogs and one field case for cats [26]. Studies showed that a very close contact with infected pigs is necessary for infection of these species. Indeed, feral cats [80] and dogs [81] from non-infected pig farms, but in contact with potentially infected fruit bats, were seronegative. In Bangladesh, human cases were associated with contact with sick cows [9] and goats [15], but no clinical or serological studies were able to confirm this transmission. In Australia, the only natural $\mathrm{HeV}$ infection in a species other than horses and bats was reported in 2011 and concerned a healthy seropositive dog from an infected property [82].

\subsection{Pigs}

In a natural context, $\mathrm{NiV}$ infection in pigs most likely occurs from oronasal contact with infected urine, faeces, or saliva from bats. The spreading of NiV from pig to pig is very high with a morbidity rate close to $100 \%$, whereas the lethality rate varies between $1 \%$ to $40 \%$ depending on the age of the animal. Infection is usually asymptomatic, but some pigs showed respiratory signs characterized by a severe nonproductive cough ("barking pig syndrome") and sudden death [20]. The study of NiV infection in pigs in an experimental context was rapidly carried out after the discovery of the virus. Oronasal and ocular routes mimic, quite well, natural infection and most infected animals remain asymptomatic [21-23] even if viral shedding is observed in nasal and pharyngeal swabs from three to seven days post-infection [23]. Sick animals present fever, depression, cough, shivering, and rarely, neurological signs including abnormal posture [24] and seizures [23]. Subcutaneous route was also tested with an increase in severity and frequency of respiratory and neurological signs [21]. Gross pathology findings include hyperplasia of submandibular, mesenteric, and bronchial lymph nodes, congestion and oedema of meninges [24] and lung consolidation. Histology reveals hyperplasia of BALT, non-suppurative meningitis, and encephalitis [21]. Immunohistology shows evidence of invasion of the central nervous system through olfactory nerves [23]. Infected pigs are able to develop neutralizing antibodies to high titers within two weeks, post-infection. In Africa, cross-reactive but not 
cross-neutralizing antibodies to $\mathrm{HeV}$ or $\mathrm{NiV}$ were found in pigs, confirming the presence of circulating henipa-like viruses in this geographic area [83].

Studies based on NiV infection of pigs provided new insights of the role of peripheral blood mononuclear cells. In contrast to what has been seen in human lymphocytes [84], certain populations of swine lymphocytes seem to be permissive to NiV infection [85]. Piglets that succumbed to NiV infection had a significant drop in the CD4+CD8- T cell frequency compared to those that survived. As these $\mathrm{T}$ helper lymphocytes aid the development of humoral responses, this observation supports the hypothesis that a rapid production of virus-specific antibodies is necessary for a fully protective anti-NiV response [85]. Moreover, experimental infection of piglets with NiV induced a lymphoid depletion in lymph nodes that was responsible for subsequent bacterial infection of immunodepressed animals [24]. Lymphotropism remains so far a unique attribute of NiV infection in swine and may account for some features of pigs as a spillover host.

The only attempt to infect pigs with $\mathrm{HeV}$ reports that nasal and oronasal inoculation usually induce respiratory symptoms both in farm pigs and minipigs. Some neurological signs (incoordination) were transiently observed on Gottingen minipigs [25]. At necropsy, a congestion of lungs and petechial hemorrhages on multiple organs were observed. Syncytial cells were frequently noticed in the respiratory epithelium of nasal turbinates and the bronchiolar epithelium. Viral RNA was detected in decreasing order for nasal, oral, rectal, and ocular swabs. Virus was successfully isolated from tonsils, bronchial-alveolar lavage fluid (BALF), lung and olfactory bulbs, nasal turbinates, submandibular and bronchial lymph nodes and swabs. Pigs developed neutralizing antibodies from day five to seven after infection.

\subsection{Horses}

Horses were used as a first animal model of henipaviruses infection, to confirm that $\mathrm{HeV}$ (called equine morbillivirus in that period) is the etiological agent of the new infectious disease [5]. The clinical course of $\mathrm{HeV}$, in both naturally and experimentally infected horses, is relatively short, with death occurring within $48 \mathrm{~h}$ after the onset of clinical signs. Experimental studies reveal an incubation period ranging from five to 10 days following infection $[5,18,27]$. Whatever the route of infection (intranasal [5,18,27], intravenous [5], or subcutaneous [18]), affected horses usually present a febrile syndrome $\left(>40{ }^{\circ} \mathrm{C}\right)$, depression, increased respiratory and heart rates, and as the disease progresses, frothy nasal discharge and neurological disabilities such as ataxia, head pressing [28], and myoclonic twitches [18]. Some horses seroconverted but still remained asymptomatic following subcutaneous [18] or natural [5] infection. Gross pathology is preferentially found in the lung area where congestion, edema [5], dilatation of the lymphatics [18], and subpleural hemorrhages [27] were shown. Histological examination usually confirms an interstitial pneumonia and a severe systemic vasculitis [5,18,27]. The presence of syncytial giant cells is detectable in lungs, kidney, lymph nodes [27], and mostly concerns endothelial cells of the blood vessels [5]. Viral isolation has been successfully performed from bronchial and oral swabs, urine as well as from brain, blood, spleen, lung, kidney, and lymph nodes [18]. Although the recovery of viral particles was not possible in rectal swabs and feces, viral RNA was found by RT-qPCR analysis [27]. Despite viral shedding in many fluids, transmission of HeV between horses remains an unlikely event [18] and seems to require very close contact in natural conditions $[86,87]$. 
Concerning $\mathrm{NiV}$, there is only one natural confirmed equine case. Histopathology on this case revealed non suppurative meningitis associated with several areas of cell depletion in the parenchyma of the brain [26].

\subsection{Cats}

The cat (Felis sylvestris catus) is a receptive animal model for both $\mathrm{HeV}$ and $\mathrm{NiV}$ infection. Rapidly after the discovery of $\mathrm{HeV}$ in 1994, the cat was tested for its susceptibility to infection [32]. Cats infected either by subcutaneous, intranasal, or oral routes become clinically ill within four to eight days $[33,34]$. The illness is restricted to a pulmonary syndrome with severe dyspnea and open mouth breathing $[18,33]$. The gross pathology is mainly focused in the lungs with hydrothorax and pulmonary edema associated with congestion and intrapulmonary hemorrhages [34]. The bronchial and mesenteric lymph nodes are enlarged, pale, and sometimes present petechial hemorrhages. The spleen is also enlarged. Histopathology of the lung is consistent with gross findings and confirmed the edema and hemorrhages. These observations are completed with a high number of alveolar macrophages, alveolar wall necrosis, and vascular lesions including thrombosis, fibrinoid necrosis, and endothelial syncytia [34]. Transmission of the virus is possible from cat to cat [33], and from cat to horse [18] but remains a relatively rare event.

The use of cats to study NiV was also assessed using either intranasal [21] or subcutaneous routes [29]. The clinical signs are relatively similar to those observed following $\mathrm{HeV}$ infection and include febrile syndrome, mental depression, tachypnea, and dyspnea [21,29]. Necropsy and histology indicate similar results to those found for $\mathrm{HeV}$. Infectivity of cats via oronasal route was not assessed for $\mathrm{NiV}$, but the vertical transmission from the female to the fetus was demonstrated. Placenta, uterine fluids, and fetal tissues were positive for NiV replication. The placenta and placental fluids contained a significant titer of virus [30] thus indicating a potential role of pregnancy in the shedding of the virus by fruit bats. Although the cat is a very susceptible model for henipaviruses infection, its utilization to study human pathology is still controversial as it does not present the neurological signs observed in humans.

The cat model was used to assess the potential of a vaccine that uses the recombinant soluble form of either $\mathrm{HeV}$ or NiV G protein, to protect against $\mathrm{NiV}$ infection [29]. Cats generated a good IgG and IgA antibody response towards $\mathrm{NiV}$, especially with $\mathrm{sHeV}$ G subunit vaccine [31], and all vaccinated animals survived a NiV challenge.

\subsection{Ferrets}

Ferrets (Mustela putorius) are a suitable model for many respiratory diseases, including Henipavirus infection. Oronasally $\mathrm{NiV}$ infected ferrets develop clinical signs within six days post-infection including fever, severe depression, tremors, myoclonus [35], and hind limb paresis [36,37] but also respiratory signs such as dyspnea, cough, and serous nasal discharge [38]. Clinical signs of $\mathrm{HeV}$ infected animals are restricted to fever, depression, and generalized tremors from day six, postinfection, whatever the dose inoculated (from 50 to $50000 \mathrm{TCID}_{50}$ ) [39]. Gross lesions are similar for both henipaviruses and show subcutaneous edema, petechial hemorrhages throughout the skin, the pulmonary parenchyma and the abdomen but also enlarged and hemorrhagic submandibular, 
retropharyngeal, bronchial, duodenal, and mesenteric lymph nodes [36-39]. Histopathology performed on infected tissues reveals acute focal necrotizing alveolitis and glomerular necrosis, systemic vasculitis with prominent endothelial syncytia, and focal necrosis of the spleen [38]. Non-suppurative meningitis was noticed in animals that presented neurological signs [38]. HeV antigens were identified in meningeal endothelial cells [39] and NiV antigens were found in the brain parenchyma [38]. Viral shedding was demonstrated by quantitative PCR from all fluids [37] especially in blood, pharyngeal and rectal swabs [38] and urine [39]. Viral isolates were successfully recovered from feces and urine in one study, especially between day seven and nine post-infection [35]. Comparative analysis between Malaysia and Bangladesh strains of NiV shows similar clinical signs. The Malaysia strain-infected ferrets present however a more pronounced hemorrhagic state. Concerning transmission of the virus, analysis of oral shedding reveals the Bangladesh strain to be more excreted than the Malaysia strain [35].

Ferrets were used to assess the efficiency of chloroquine as potential treatment of NiV infection, where no significant effect was observed [37]. They were then used in the successful evaluation of passive [38] or active [39] immunotherapy respectively based on human monoclonal antibodies or recombinant $\mathrm{HeV} \mathrm{G}$ glycoprotein-based subunit vaccine. Neutralizing antibodies from ferrets infected by the Cedar virus were detected as early as 10 days post-infection and at high titer 21 days postinfection although the ferrets remained clinically healthy [4].

\section{Non-Human Primate Models}

The development of primate models is necessary for preclinical tests of preventive and therapeutic anti-viral approaches. The first nonhuman primate model described for NiV infection was the Squirrel monkey (Saimiri sciureus) [40]. Clinical illness with an acute neurological and respiratory syndrome associated with high mortality was observed in intravenously infected monkeys. Viral RNA and antigens were detected in different tissues (Figure 1). High antibody-neutralization titers were found only in monkeys that survived infection. Similarly to what has been shown in hamsters, free virus was not found in plasma of Squirrel monkeys, but rather virus was associated with the cell compartment, in accordance with the hypothesis that $\mathrm{NiV}$ could use circulating cells as carriers for efficient transmission within a host [84]. As observed in human infection of the Malaysian outbreak [88], only half of the challenged animals exhibited clinical signs, making this model potentially interesting to understand NiV pathogenesis in humans, although less convenient, compared to the other described animal models for the assessment of anti-viral approaches.

In a second primate model, African green monkeys (AGM) were evaluated for both $\mathrm{NiV}$ and $\mathrm{HeV}$ infection [41,43]. Virus challenge by intratracheal inoculation, of either $\mathrm{NiV}$ or $\mathrm{HeV}$, resulted in a rapid spread of the virus and infection of multiple organs, leading to high mortality. Severe respiratory pathology, neurological disease, endothelial syncytia, and generalized vasculitis were observed with both viruses. Immunohistochemical analysis showed the presence of viral antigens in different organs including lungs, the brainstem, and spleen. 
Figure 1. Immunohistochemistry analysis from NiV-infected Squirrel Monkeys. (a) Lung. Inflammation associated with positive immunostaining (brown) in the alveolar wall; (b) Spleen. Positive immunostaining (brown) located in the white pulp. Original magnification $20 \times$.
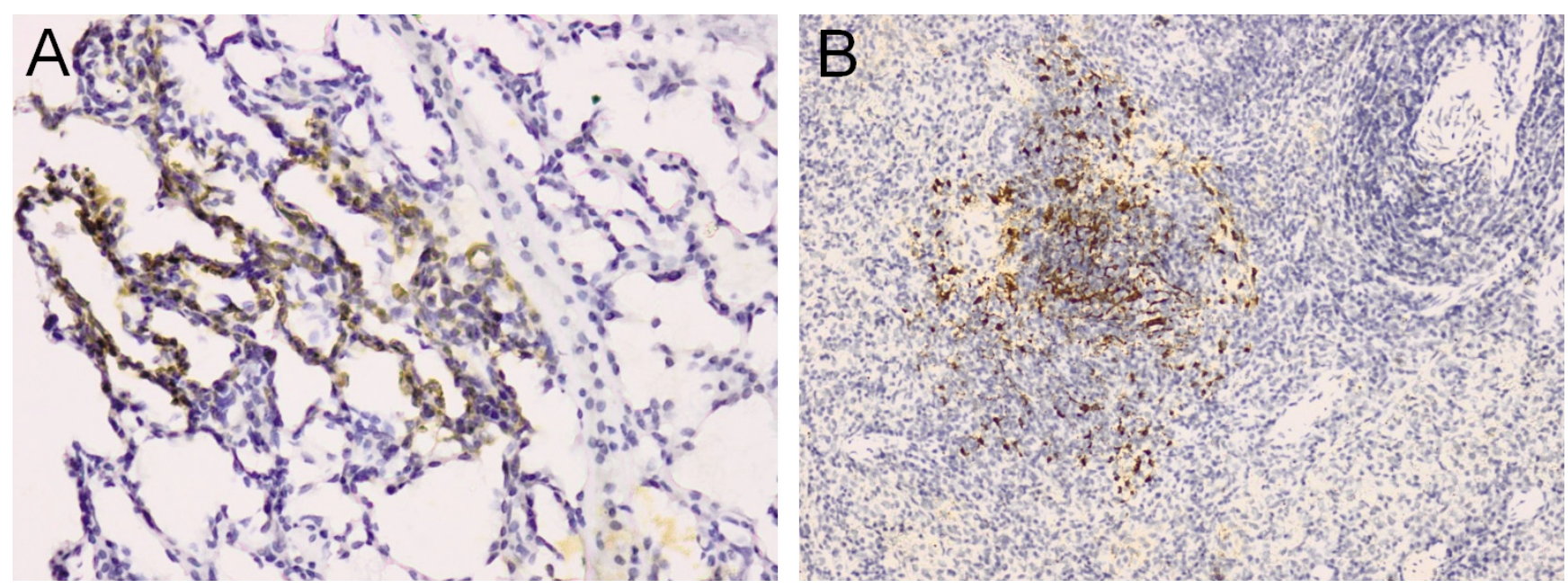

The AGM model was shown to be a useful tool to evaluate antiviral therapy and prophylaxis in primates. The efficiency of ribavirin as a prophylactic and postexposure treatment was evaluated in $\mathrm{HeV}$ infection, demonstrating that it could delay disease onset without having significant benefit for disease progression and outcome [43]. Passive and active immunization against $\mathrm{HeV}$ and $\mathrm{NiV}$, respectively, were proven to be successful in this model with the use of a recombinant human monoclonal antibody possessing virus-neutralizing properties [44] and a $G$ glycoprotein subunit vaccine [42].

\section{Rodent Models}

\subsection{Golden Syrian Hamster}

The Golden Syrian Hamster (Mesocricetus auratus) is a commonly used model to study henipaviruses pathogenesis as the clinical signs and pathological lesions observed following intranasal or intraperitoneal inoculation highly resemble those observed in humans. When infected with NiV, the golden hamster shows a progressive behavioral deterioration, lethargy, imbalance, muscle twitching, tremors, and limb paralysis [47]. At high doses $\left(10^{5} \mathrm{TCID}_{50}\right)$, and particularly when inoculated intranasally, the clinical signs are mainly restricted to an acute respiratory syndrome with labored breathing and serosanguineous nasal exudates [48]. Radiography experiments revealed that morphological changes of the lung begin as rapidly as two days post-infection. At necropsy, the edema of the lung was evidenced by a two times increase in lung weight. Viral isolates can be recovered from lung and tracheal tissues. Syncytial cells were observed in bronchial epithelium and endothelium of blood vessels although no viremia was detected. Many hemorrhages were also noted in the lung parenchyma, especially with $\mathrm{HeV}$ [48]. Lower doses also result in respiratory signs but are followed by neurological disabilities. In these animals, the lesions are widespread and can be found in heart, liver, kidney, bladder, brain, lung, and nasal epithelium [48]. RT-qPCR analysis revealed the presence 
of the virus in these organs, and also in urine. The lesions were largely represented by vasculitis but also inflammation in lung and brain where infected neurons were found [47].

Recent immunohistological evidence suggests that $\mathrm{NiV}$ is able to rapidly invade the central nervous system via olfactory route following an intranasal challenge [89]. The breach of the blood brain barrier, evidenced by an Evans Blue experiment, also reveals that the endothelium of the brain is permeable enough to let the virus circulate from systemic circulation to the brain [48]. Isolation of $\mathrm{NiV}$ is restricted to brain and kidney when animals are infected intranasally but is also possible from urine, spinal cord, lung, spleen, and liver when infected intraperitoneally [47]. Despite excretion of the virus in urine, transmission studies reveal that contamination by direct contact is not frequent and even less via fomites or aerosol routes [49].

Similarly to tests performed in ferrets [35], comparison of the pathogenicity of NiV isolates from Malaysia and Bangladesh was performed in hamsters. Results suggest that the Malaysia isolate has a faster replication rate and is more pathogenic than the Bangladesh isolate in which death is delayed. However, the clinical signs of the two isolates remain identical as well as viral distribution. In accordance with the accelerated pathology observed with the Malaysia isolate, the host immune response genes (especially IL-4, CXCL10, IL-6, TNF $\alpha$ and IFN $\gamma$ ) are activated earlier than for the Bangladesh isolate [50].

Overall, hamsters provide a significant improvement in understanding of henipaviruses immunopathogenesis. Their use has helped to determine the role of the non-structural proteins during the course of infection. Indeed, infection of hamsters with a recombinant virus lacking $\mathrm{W}$ protein remains highly lethal whereas recombinant viruses deficient for $\mathrm{V}$ or $\mathrm{C}$ proteins are nonpathogenic [51], reflecting the potential role of the $\mathrm{V}$ and $\mathrm{C}$ proteins in the dysregulation of the innate immune response. Furthermore, C-deficient NiV induces higher recruitment of inflammatory cells and less intensive histopathological lesions than wild-type $\mathrm{NiV}$, in different organs of infected hamsters, thus suggesting the important role of NiV C protein in the regulation of early proinflammatory responses [52]. Finally, in agreement to the results obtained from transcriptomic analysis of $\mathrm{NiV}$ infected endothelial cells and patients succumbed to $\mathrm{NiV}$-induced encephalitis, $\mathrm{NiV}$ infection in hamsters induces the important expression of proinflammatory chemokine CXCL10 in different organs $[48,53,90]$. This cytokine was confirmed to play an important role in $\mathrm{HeV}$ pathogenesis as well, and it was demonstrated that the development of neurological signs in both $\mathrm{NiV}$ and $\mathrm{HeV}$ infection coincided with tumor necrosis factor alpha and interleukin 1 production in hamsters [48,53].

Hamsters are also able to mount a good henipaviruses-specific seroneutralizing response after infection. They are thus extensively used to study potential vaccines [54,58], to monitor passive immunization assays $[54,55,59]$ or to test new treatments [56,57] and they remain commonly used by different groups.

\subsection{Guinea Pig}

The Guinea Pig (Cavia porcellus) was the first susceptible rodent model developed to study infection with henipaviruses. However, due to high variability in results and development of new models, it lost its importance as a relevant animal model for the study of Henipavirus infection. Intradermal [60] and intranasal $[25,60]$ inoculation were proven to be inefficient but subcutaneous injection of a high dose 
of $\mathrm{HeV}[34,60,61]$, or intraperitoneal injection of $\mathrm{NiV}$ [17], resulted in slight clinical signs usually associated with a systemic spreading of the virus revealed by immunohistochemistry, or did not show any clinical signs at all [47]. The observed clinical signs include depression, ruffled fur, and abnormal behavior followed by twitching, ataxia, and sudden death [17,60]. Necropsy revealed general cyanosis, congestion, and edema, especially in the lungs [34]. Histopathology and immunohistochemistry confirmed the presence of several syncytia and infected cells in the endothelium of blood vessels [34], lymphoid organs [91], brain, kidney, and transitional epithelium of the bladder [60,91], and myometrium and endometrium of the uterus [17,91]. Consistent with histological results, viral particles were isolated from heart, lung, kidney [17], urine, brain [60], uterus or placenta, and even from fetus [61]. If RT-qPCR allowed the detection of viral RNA in oral swabs [25], isolation of the virus from nasal, oral, rectal, and conjunctival swabs remained impossible [60]. Seroneutralizing antibodies are usually found in animals that survived [25,60]. Guinea Pigs were also used to analyze pathogenicity of the Cedar virus. Although they produced seroneutralizing antibodies 21 days after infection, they did not develop any visible clinical signs [4].

\subsection{Mice}

As murine models are very convenient to study viral infections and provide a well-developed experimental toolbox for analysis in immunovirology, the assessment of mice as a possible animal model for henipaviruses was undertaken rapidly after the discovery of both viruses. Despite possessing functional Ephrin (EFN) B2 and B3 virus receptors, mice were shown to be resistant to henipaviruses inoculation by intranasal [47], intraperitoneal [32,47], or subcutaneous [36] routes unless administered intracranially into suckling Balb/c mice [29]. Recently, two approaches were explored to create susceptible murine models of $\mathrm{HeV}$ and $\mathrm{NiV}$ infection.

\subsubsection{Aged Mice}

Mice of different strains and ages were challenged with 50000 TCID $_{50}$ of $\mathrm{HeV}$ either by intranasal or subcutaneous routes [46]. Results show that elderly mice (12 months old) from both strains (C57BL/6 or BALB/c) are susceptible to the disease when inoculated intranasally whereas subcutaneously injected mice and juveniles (eight weeks old) are resistant. Neurological symptoms resemble those observed in humans. They include ataxia, muscle tremors, hypersensitivity, and were followed by death. $\mathrm{HeV}$ antigen was only found in the brain, either by immunohistochemistry or by RT-qPCR, and seems to be restricted to neurons of the primary olfactory complex. Indeed, as demonstrated in hamsters [89] or in pigs [23], the central nervous system (CNS) can be reached without crossing the blood-brain-barrier via olfactory nerves after an intranasal inoculation of the virus. Histology analysis showed severe encephalitis characterized by neuronal degeneration, gliosis, perivascular cuffing, and associated to non-suppurative meningitis. Virus isolation was not possible from infected brains. In accordance with the RT-qPCR results, systemic lesions such as typical generalized vasculitis were totally absent in animals. However, a time-course study performed on aged $\mathrm{BALB} / \mathrm{c}$ mice inoculated intranasally revealed that virus isolation was possible from lungs between day four and day 10, post infection, suggesting a transient infection of the lower respiratory tract. Seroneutralizing antibodies were sometimes detected, but at very low levels. The susceptibility of aged 
mice probably results from immunological changes that occur with aging. Indeed, defects of the adaptive immunity [92,93], as well as innate immune system, including macrophages functions [94], dendritic cells migration and interferon- $\alpha$ production by plasmacytoid dendritic cells [94] were all shown in old mice.

\subsubsection{Transgenic Mice}

Transgenesis in mice is a powerful and well-established approach that allows the addition of exogenous genes (transgenic and knock-in) or the inactivation of endogenous genes (knock-out, KO). Transgenic mice are important animal models as they make possible the functional assessment of different genes and have already provided remarkable insights in diverse aspects of viral pathogenesis. As the type I interferon (IFN-I) system is one of the first immune pathways triggered by viruses, mice lacking the IFN-I receptor (IFNAR KO) were generated in 1994 and shown to be sensitive to infection with VSV and LCMV, in contrast to wild type mice [95]. This murine model was used to evaluate the susceptibility to $\mathrm{HeV}$ and $\mathrm{NiV}$ infection as well [45].

IFNAR KO mice, backcrossed on C57BL/6 genetic background, were challenged with doses of $\mathrm{NiV}$ or $\mathrm{HeV}$ ranging from $100 \mathrm{pfu}$ to $10^{6} \mathrm{pfu}$ [45]. The three inoculation routes tested (intracranially, intraperitoneally, and intranasally) resulted in high mortality in IFNAR KO mice whereas only the intracranial route was fatal in WT mice; thus suggesting the important role of IFN-I signaling in the murine resistance towards henipaviruses. IFNAR KO mice showed clinical signs similar to those observed in humans and other animal models starting with agitation, lack of grooming, then followed by lordosis, expression of pain and discomfort, prostration, and finally locomotor disabilities and paralysis. All animals died between days six and nine when injected intraperitonally with $10^{6} \mathrm{pfu}$.

Gross pathology reveals congestion with scattered small hemorrhagic lesions in brain but also in liver and kidney, especially for NiV-infected animals (Figure 2). Histopathology shows that the brain is particularly affected with the presence of numerous spots of leukocyte infiltration, perivascular cuffing, hemorrhages, and non-suppurative meningitis (Figure 2A). Immunohistochemistry (IHC) analysis confirmed the presence of the virus in neurons and ependymal cells. In the lungs, intense inflammation with edema, focal necrotizing alveolitis and vasculitis was noticed and antigen presence was confirmed by IHC (Figure 2B-D). As a particularity of this model, hepatic lesions are severe with $\mathrm{NiV}$ infection and result in focal necrosis, vasculitis, and presence of several syncytial cells. The amount of viral RNA was quantified by RT-qPCR and revealed that all sampled organs (brain, lung, spleen, and liver) were positive with the highest quantity in lungs. Hepatic lesions are also observed to a lesser extent in hamsters [47] and NiV RNA was found in liver of ferrets [38] and African green monkeys [41]. Such observations suggest that IFN is a potent controller of pathogenesis in the liver.

IFNAR KO mice sub-lethally infected either by $\mathrm{NiV}$ or HeV develop a high titer of seroneutralizing antibody response within three weeks, demonstrating thus their capacity to efficiently mount virusspecific humoral immune response. This new model suggests the critical role of type I signaling in the control of $\mathrm{HeV}$ and $\mathrm{NiV}$ infection and provides the possibility to use numerous and powerful tools available for mice to further study henipaviruses pathogenesis, prophylaxis, and treatment. 
Figure 2. Gross pathology and immunohistology of IFNAR KO mice infected with NiV (a) Brain showing hemorrhages and congestion; (b) Vasculitis associated with leukocytes infiltration of the brain parenchyma; (c) Positive immunostaining of NiV antigens in the ependymal layer of a ventricle; (d) Hemorrhages, vasculitis and pronounced meningitis.
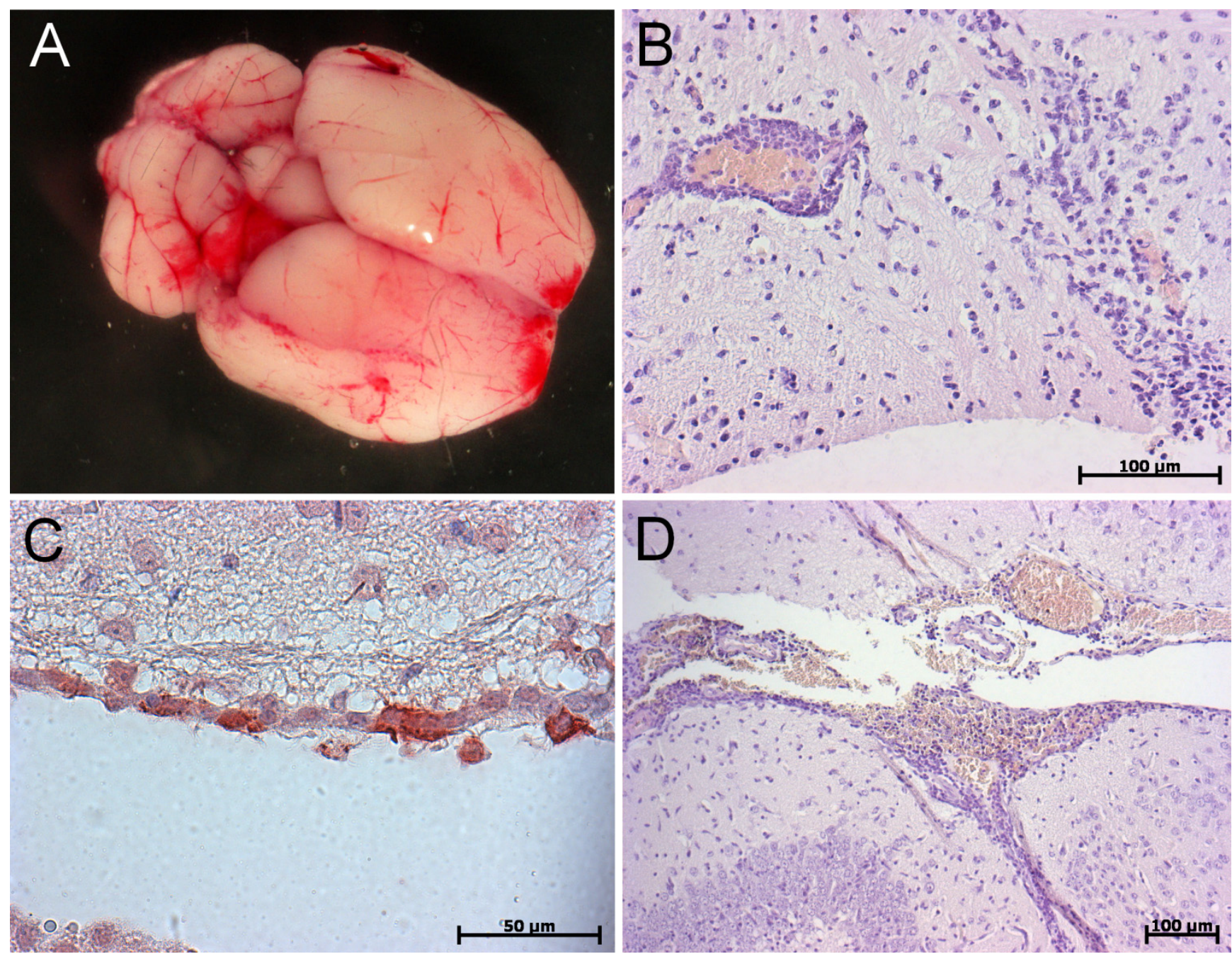

\section{Conclusions and Perspectives}

The changing ecological pressures on flying foxes owing to deforestation, urban development, altered foraging, and behavioral patterns all play a role in the continuing reemergence of Henipavirus infections. Since 1994, animal models have provided significant advances in fundamental research into henipaviruses and given critical support to discover and assess potential prophylactic and therapeutic treatments. Future challenges in this field will include the comprehension of the mechanisms allowing the efficient control of viral replication in fruit bats, which can give rise to original therapeutic approaches. The recent discovery of the third nonpathogenic member of Henipavirus genus, the Cedar virus, offers new possibilities for comparative analysis of henipaviruses immunopathogenesis. The use of appropriate laboratory animal models is critical for correct studies and further development of antiviral therapeutics and vaccines. As showed in Table 1, the choice of the most accurate animal model strongly depends of the goal of the study, and should be done in accordance with the particularities and limitations of each model. The recent discovery of susceptibility of genetically 
modified mice to Henipavirus infection opens new avenues in the field of the immunobiology of these viruses. The use of a small animal model for which many experimental tools are available should improve our understanding of the control of this highly lethal infection and will provide significant help to develop new treatments and prevention.

\section{Acknowledgments}

The work was supported by ANR, ECOFECT and INSERM, KD was supported by DGA and INSERM.

\section{Conflict of Interest}

The authors declare no conflict of interest.

\section{References}

1. Eaton, B.T.; Broder, C.C.; Middleton, D.; Wang, L.-F. Hendra and Nipah Viruses: different and dangerous. Nat. Rev. Micro. 2006, 4, 23-35.

2. Marsh, G.A.; Wang, L.-F. Hendra and Nipah viruses: Why are they so deadly? Curr. Opin. Virol. 2012, 2, 242-247.

3. Field, H.; Kung, N. Henipaviruses - unanswered questions of lethal zoonoses. Curr. Opin. Virol. 2011, 1, 658-661.

4. Marsh, G.A.; De Jong, C.; Barr, J.A.; Tachedjian, M.; Smith, C.; Middleton, D.; Yu, M.; Todd, S.; Foord, A.J.; Haring, V.; et al. Cedar virus: A novel henipavirus isolated from australian bats. PLoS Pathogens 2012, 8, e1002836.

5. Murray, K.; Rogers, R.; Selvey, L.; Selleck, P.; Hyatt, A.; Gould, A.; Gleeson, L.; Hooper, P.; Westbury, H. A novel morbillivirus pneumonia of horses and its transmission to humans. Emerg. Infect. Dis. 1995, 1, 31-33.

6. Chua, K.B.; Bellini, W.J.; Rota, P.A.; Harcourt, B.H.; Tamin, A.; Lam, S.K.; Ksiazek, T.G.; Rollin, P.E.; Zaki, S.R.; Shieh, W.-J.; et al. Nipah virus: A recently emergent deadly paramyxovirus. Science 2000, 288, 1432-1435.

7. Wong, K.T.; Shieh, W.-J.; Kumar, S.; Norain, K.; Abdullah, W.; Guarner, J.; Goldsmith, C.S.; Chua, K.B.; Lam, S.K.; Tan, C.T.; et al. Nipah virus infection. Am. J. Pathol. 2002, 161, 2153-2167.

8. Chadha, M.S.; Comer, J.A.; Lowe, L.; Rota, P.A.; Rollin, P.E.; Bellini, W.J.; Ksiazek, T.G.; Mishra, A. Nipah virus-associated encephalitis outbreak, Siliguri, India. Emerg. Infect. Dis. 2006, $12,235-240$.

9. Hsu, V.P.; Hossain, M.J.; Parashar, U.D.; Ali, M.M.; Ksiazek, T.G.; Kuzmin, I.; Niezgoda, M.; Rupprecht, C.; Bresee, J.; Breiman, R.F. Nipah virus encephalitis reemergence, Bangladesh. Emerg. Infect. Dis. 2004, 10, 2082-2087.

10. Stone, R. Breaking the Chain in Bangladesh. Science 2011, 331, 1128-1131. 
11. Harcourt, B.H.; Lowe, L.; Tamin, A.; Liu, X.; Bankamp, B.; Bowden, N.; Rollin, P.E.; Comer, J.A.; Ksiazek, T.G.; Hossain, M.J.; et al. Genetic characterization of Nipah virus, Bangladesh, 2004. Emerg. Infect. Dis. 2005, 11, 1594-1597.

12. Lo, M.K.; Lowe, L.; Hummel, K.B.; Sazzad, H.M.S.; Gurley, E.S.; Hossain, M.J.; Luby, S.P.; Miller, D.M.; Comer, J.A.; Rollin, P.E.; et al. Characterization of Nipah Virus from Outbreaks in Bangladesh, 2008-2010. Emerg. Infect. Dis. 2012, 18, 248-255.

13. Tan, C.T.; Goh, K.J.; Wong, K.T.; Sarji, S.A.; Chua, K.B.; Chew, N.K.; Murugasu, P.; Loh, Y.L.; Chong, H.T.; Tan, K.S.; et al. Relapsed and late-onset Nipah encephalitis. Ann. Neurol. 2002, 51, 703-708.

14. Lo, M.K.; Rota, P.A. The emergence of Nipah virus, a highly pathogenic paramyxovirus. J. Clin. Virol. 2008, 43, 396-400.

15. Luby, S.P.; Gurley, E.S.; Hossain, M.J. Transmission of human infection with Nipah virus. Clin. Infect. Dis. 2009, 49, 1743-1748.

16. Drexler, J.F.; Corman, V.M.; Müller, M.A.; Maganga, G.D.; Vallo, P.; Binger, T.; Gloza-Rausch, F.; Rasche, A.; Yordanov, S.; Seebens, A.; et al. Bats host major mammalian paramyxoviruses. Nat. Commun. 2012, 3, 796.

17. Middleton, D.J.; Morrissy, C.J.; Van der Heide, B.M.; Russell, G.M.; Braun, M.A.; Westbury, H.A.; Halpin, K.; Daniels, P.W. Experimental Nipah virus infection in pteropid bats (Pteropus poliocephalus). J. Comp. Pathol. 2007, 136, 266-272.

18. Williamson, M.; Hooper, P.; Selleck, P.; Gleeson, L.; Daniels, P.; Westbury, H.; Murray, P. Transmission studies of Hendra virus (equine morbilli-virus) in fruit bats, horses and cats. Aust. Vet. J. 1998, 76, 813-818.

19. Halpin, K.; Hyatt, A.D.; Fogarty, R.; Middleton, D.; Bingham, J.; Epstein, J.H.; Rahman, S.A.; Hughes, T.; Smith, C.; Field, H.E.; Daszak, P. Pteropid bats are confirmed as the reservoir hosts of henipaviruses: a comprehensive experimental study of virus transmission. Am. J. Trop. Med. Hyg. 2011, 85, 946-951.

20. Mohd Nor, M.N.; Gan, C.H.; Ong, B.L. Nipah virus infection of pigs in peninsular Malaysia. Rev. Off. Int. Epizoot. 2000, 19, 160-165.

21. Middleton, D.J.; Westbury, H.A.; Morrissy, C.J.; Van der Heide, B.M.; Russell, G.M.; Braun, M.A.; Hyatt, A.D. Experimental Nipah virus infection in pigs and cats. J. Comp. Pathol. 2002, 126, 124-136.

22. Weingartl, H.M.; Berhane, Y.; Caswell, J.L.; Loosmore, S.; Audonnet, J.-C.; Roth, J.A.; Czub, M. Recombinant Nipah virus vaccines protect pigs against challenge. J. Virol. 2006, 80, 7929-7938.

23. Weingartl, H.; Czub, S.; Copps, J.; Berhane, Y.; Middleton, D.; Marszal, P.; Gren, J.; Smith, G.; Ganske, S.; Manning, L.; Czub, M. Invasion of the Central Nervous System in a Porcine Host by Nipah Virus. J. Virol. 2005, 79, 7528-7534.

24. Berhane, Y.; Weingartl, H.M.; Lopez, J.; Neufeld, J.; Czub, S.; Embury-Hyatt, C.; Goolia, M.; Copps, J.; Czub, M. Bacterial infections in pigs experimentally infected with Nipah virus. Transbound. Emerg. Dis. 2008, 55, 165-174.

25. Li, M.; Embury-Hyatt, C.; Weingartl, H.M. Experimental inoculation study indicates swine as a potential host for Hendra virus. Vet. Res. 2010, 41, 33. 
26. Hooper, P.; Zaki, S.; Daniels, P.; Middleton, D. Comparative pathology of the diseases caused by Hendra and Nipah viruses. Microbes Infect. 2001, 3, 315-322.

27. Marsh, G.; Haining, J.; Hancock, T.; Robinson, R.; Foord, A.; Barr, J.; Riddell, S.; Heine, H.; White, J.; Crameri, G.; et al. Experimental Infection of Horses with Hendra Virus/Australia/Horse/2008/Redlands. Emerg. Infect. Dis. 2011, 17.

28. Rogers, R.J.; Douglas, I.C.; Baldock, F.C.; Glanville, R.J.; Seppanen, K.T.; Gleeson, L.J.; Selleck, P.N.; Dunn, K.J. Investigation of a second focus of equine morbillivirus infection in coastal Queensland. Aust. Vet. J. 1996, 74, 243-244.

29. Mungall, B.A.; Middleton, D.; Crameri, G.; Bingham, J.; Halpin, K.; Russell, G.; Green, D.; McEachern, J.; Pritchard, L.I.; Eaton, B.T.; et al. Feline model of acute nipah virus infection and protection with a soluble glycoprotein-based subunit vaccine. J. Virol. 2006, 80, 12293-12302.

30. Mungall, B.A.; Middleton, D.; Crameri, G.; Halpin, K.; Bingham, J.; Eaton, B.T.; Broder, C.C. Vertical transmission and fetal replication of nipah virus in an experimentally infected cat. $J$. Infect. Dis. 2007, 196, 812-816.

31. McEachern, J.A.; Bingham, J.; Crameri, G.; Green, D.J.; Hancock, T.J.; Middleton, D.; Feng, Y.R.; Broder, C.C.; Wang, L.-F.; et al. A recombinant subunit vaccine formulation protects against lethal Nipah virus challenge in cats. Vaccine 2008, 26, 3842-3852.

32. Westbury, H.A.; Hooper, P.T.; Selleck, P.W.; Murray, P.K. Equine morbillivirus pneumonia: susceptibility of laboratory animals to the virus. Aust. Vet. J. 1995, 72, 278-279.

33. Westbury, H.A.; Hooper, P.T.; Brouwer, S.L.; Selleck, P.W. Susceptibility of cats to equine morbillivirus. Aust. Vet. J. 1996, 74, 132-134.

34. Hooper, P.T.; Westbury, H.A.; Russell, G.M. The lesions of experimental equine morbillivirus disease in cats and guinea pigs. Vet. Pathol. 1997, 34, 323-329.

35. Clayton, B.A.; Middleton, D.; Bergfeld, J.; Haining, J.; Arkinstall, R.; Wang, L.; Marsh, G.A. Transmission routes for nipah virus from Malaysia and Bangladesh. Emerg. Infect. Dis. 2012, 18, 1983-1993.

36. Bossart, K.N.; Bingham, J.; Middleton, D. Targeted Strategies for Henipavirus Therapeutics. Open Virol. J. 2007, 1, 14-25.

37. Pallister, J.; Middleton, D.; Crameri, G.; Yamada, M.; Klein, R.; Hancock, T.J.; Foord, A.; Shiell, B.; Michalski, W.; Broder, C.C.; et al. Chloroquine administration does not prevent nipah virus infection and disease in ferrets. J. Virol. 2009, 83, 11979-11982.

38. Bossart, K.N.; Zhu, Z.; Middleton, D.; Klippel, J.; Crameri, G.; Bingham, J.; McEachern, J.A.; Green, D.; Hancock, T.J.; Chan, Y.-P.; et al. A neutralizing human monoclonal antibody protects against lethal disease in a new ferret model of acute nipah virus infection. PLoS Pathog. 2009, 5, e1000642.

39. Pallister, J.; Middleton, D.; Wang, L.-F.; Klein, R.; Haining, J.; Robinson, R.; Yamada, M.; White, J.; Payne, J.; Feng, Y.-R.; et al. A recombinant Hendra virus G glycoprotein-based subunit vaccine protects ferrets from lethal Hendra virus challenge. Vaccine 2011, 29, 5623-5630.

40. Marianneau, P. Experimental infection of squirrel monkeys with Nipah virus. Emerg. Infect. Dis. 2010, 16, 507-510. 
41. Geisbert, T.W.; Daddario-DiCaprio, K.M.; Hickey, A.C.; Smith, M.A.; Chan, Y.-P.; Wang, L.-F.; Mattapallil, J.J.; Geisbert, J.B.; Bossart, K.N.; Broder, C.C. Development of an Acute and Highly Pathogenic Nonhuman Primate Model of Nipah Virus Infection. PLoS One 2010, 5, e10690.

42. Bossart, K.N.; Rockx, B.; Feldmann, F.; Brining, D.; Scott, D.; Lacasse, R.; Geisbert, J.B.; Feng, Y.-R.; Chan, Y.-P.; Hickey, A.C.; et al. A hendra virus g glycoprotein subunit vaccine protects african green monkeys from nipah virus challenge. Sci. Transl. Med. 2012, 4, 146ra107.

43. Rockx, B.; Bossart, K.N.; Feldmann, F.; Geisbert, J.B.; Hickey, A.C.; Brining, D.; Callison, J.; Safronetz, D.; Marzi, A.; Kercher, L.; et al. A novel model of lethal hendra virus infection in african green monkeys and the effectiveness of ribavirin treatment. J. Virol. 2010, 84, 9831-9839.

44. Bossart, K.N.; Geisbert, T.W.; Feldmann, H.; Zhu, Z.; Feldmann, F.; Geisbert, J.B.; Yan, L.; Feng, Y.-R.; Brining, D.; et al. A neutralizing human monoclonal antibody protects african green monkeys from hendra virus challenge. Sci. Transl. Med. 2011, 3, 105ra103.

45. Dhondt, K.P.; Mathieu, C.; Chalons, M.; Reynaud, J.M.; Vallve, A.; Raoul, H.; Horvat, B. Type I interferon signaling protects mice from lethal Henipavirus infection. J. Infect. Dis. 2012, 207, $142-151$.

46. Dups, J.; Middleton, D.; Yamada, M.; Monaghan, P.; Long, F.; Robinson, R.; Marsh, G.A.; Wang, L.-F. A new model for hendra virus encephalitis in the mouse. PLoS One 2012, 7, e40308.

47. Wong, K.T.; Grosjean, I.; Brisson, C.; Blanquier, B.; Fevre-Montange, M.; Bernard, A.; Loth, P.; Georges-Courbot, M.-C.; Chevallier, M.; Akaoka, H.; et al. A golden hamster model for human acute Nipah virus infection. Am. J. Pathol. 2003, 163, 2127-2137.

48. Rockx, B.; Brining, D.; Kramer, J.; Callison, J.; Ebihara, H.; Mansfield, K.; Feldmann, H. Clinical outcome of henipavirus infection in hamsters is determined by the route and dose of infection. $J$. Virol. 2011, 85, 7658-7671.

49. De Wit, E.; Bushmaker, T.; Scott, D.; Feldmann, H.; Munster, V.J. Nipah virus transmission in a hamster model. PLoS Negl. Trop. Dis. 2011, 5, e1432.

50. Debuysscher, B.L.; De Wit, E.; Munster, V.J.; Scott, D.; Feldmann, H.; Prescott, J. Comparison of the pathogenicity of nipah virus isolates from bangladesh and malaysia in the Syrian hamster. PLoS Negl. Trop. Dis. 2013, 7, e2024.

51. Yoneda, M.; Guillaume, V.; Sato, H.; Fujita, K.; Georges-Courbot, M.-C.; Ikeda, F.; Omi, M.; Muto-Terao, Y.; Wild, T.F.; Kai, C. The Nonstructural proteins of nipah virus play a key role in pathogenicity in experimentally infected animals. PLoS One 2010, 5, e12709.

52. Mathieu, C.; Guillaume, V.; Volchkova, V.A.; Pohl, C.; Jacquot, F.; Looi, R.Y.; Wong, K.T.; Legras-Lachuer, C.; Volchkov, V.E.; Lachuer, J.; et al. Nonstructural Nipah virus C protein regulates both the early host proinflammatory response and viral virulence. J. Virol. 2012, In Press.

53. Mathieu, C.; Guillaume, V.; Sabine, A.; Ong, K.C.; Wong, K.T.; Legras-Lachuer, C.; Horvat, B. Lethal Nipah virus infection induces rapid overexpression of CXCL10. PLoS One 2012, 7, e32157.

54. Guillaume, V.; Contamin, H.; Loth, P.; Georges-Courbot, M.-C.; Lefeuvre, A.; Marianneau, P.; Chua, K.B.; Lam, S.K.; Buckland, R.; Deubel, V.; et al. Nipah virus: Vaccination and passive protection studies in a hamster model. J. Virol. 2004, 78, 834-840. 
55. Guillaume, V.; Contamin, H.; Loth, P.; Grosjean, I.; Georges-Courbot, M.C.; Deubel, V.; Buckland, R.; Wild, T.F. Antibody prophylaxis and therapy against Nipah virus infection in hamsters. J. Virol. 2006, 80, 1972-1978.

56. Freiberg, A.N.; Worthy, M.N.; Lee, B.; Holbrook, M.R. Combined chloroquine and ribavirin treatment does not prevent death in a hamster model of Nipah and Hendra virus infection. J. Gen. Virol. 2010, 91, 765-772.

57. Georges-Courbot, M.C.; Contamin, H.; Faure, C.; Loth, P.; Baize, S.; Leyssen, P.; Neyts, J.; Deubel, V. Poly(I)-poly(C12U) but not ribavirin prevents death in a hamster model of Nipah virus infection. Antimicrob. Agents Chemother. 2006, 50, 1768-1772.

58. Ploquin, A.; Szécsi, J.; Mathieu, C.; Guillaume, V.; Barateau, V.; Ong, K.C.; Wong, K.T.; Cosset, F.-L.; Horvat, B.; Salvetti, A. Protection against henipavirus infection by use of recombinant adeno-associated virus-vector vaccines. J. Infect. Dis. 2013, 207, 469-478.

59. Guillaume, V.; Wong, K.T.; Looi, R.Y.; Georges-Courbot, M.-C.; Barrot, L.; Buckland, R.; Wild, T.F.; Horvat, B. Acute Hendra virus infection: Analysis of the pathogenesis and passive antibody protection in the hamster model. Virology 2009, 387, 459-465.

60. Williamson, M.M.; Hooper, P.T.; Selleck, P.W.; Westbury, H.A.; Slocombe, R.F.S. A guinea-pig model of hendra virus encephalitis. J. Comp. Pathol. 2001, 124, 273-279.

61. Williamson, M.M.; Hooper, P.T.; Selleck, P.W.; Westbury, H.A.; Slocombe, R.F. Experimental hendra virus infectionin pregnant guinea-pigs and fruit Bats (Pteropus poliocephalus). J. Comp. Pathol. 2000, 122, 201-207.

62. Calisher, C.H.; Childs, J.E.; Field, H.E.; Holmes, K.V.; Schountz, T. Bats: Important reservoir hosts of emerging viruses. Clin. Microbiol. Rev. 2006, 19, 531-545.

63. Wong, S.; Lau, S.; Woo, P.; Yuen, K.-Y. Bats as a continuing source of emerging infections in humans. Rev. Med. Virol. 2007, 17, 67-91.

64. Young, P.L.; Halpin, K.; Selleck, P.W.; Field, H.; Gravel, J.L.; Kelly, M.A.; Mackenzie, J.S. Serologic evidence for the presence in Pteropus bats of a paramyxovirus related to equine morbillivirus. Emerg. Infect. Dis. 1996, 2, 239-240.

65. Halpin, K.; Young, P.L.; Field, H.E.; Mackenzie, J.S. Isolation of Hendra virus from pteropid bats: a natural reservoir of Hendra virus. J. Comp. Pathol. 2000, 81, 1927-1932.

66. Yob, J.M.; Field, H.; Rashdi, A.M.; Morrissy, C.; Van der Heide, B.; Rota, P.; Bin Adzhar, A.; White, J.; Daniels, P.; Jamaluddin, A.; et al. Nipah virus infection in bats (order Chiroptera) in peninsular Malaysia. Emerg. Infect. Dis. 2001, 7, 439-441.

67. Yadav, P.D.; Raut, C.G.; Shete, A.M.; Mishra, A.C.; Towner, J.S.; Nichol, S.T.; Mourya, D.T. Detection of Nipah virus RNA in fruit bat (Pteropus giganteus) from India. Am. J. Trop. Med. Hyg. 2012, 87, 576-578.

68. Olson, J.G.; Rupprecht, C.; Rollin, P.E.; An, U.S.; Niezgoda, M.; Clemins, T.; Walston, J.; Ksiazek, T.G. Antibodies to Nipah-like virus in bats (Pteropus lylei), Cambodia. Emerg. Infect. Dis. 2002, 8, 987-988.

69. Reynes, J.-M.; Counor, D.; Ong, S.; Faure, C.; Seng, V.; Molia, S.; Walston, J.; Georges-Courbot, M.C.; Deubel, V.; Sarthou, J.-L. Nipah virus in Lyle's flying foxes, Cambodia. Emerg. Infect. Dis. 2005, 11, 1042-1047. 
70. Sendow, I.; Field, H.E.; Curran, J.; Darminto; Morrissy, C.; Meehan, G.; Buick, T.; Daniels, P. Henipavirus in Pteropus vampyrus bats, Indonesia. Emerg. Infect. Dis. 2006, 12, 711-712.

71. Wacharapluesadee, S.; Boongird, K.; Wanghongsa, S.; Ratanasetyuth, N.; Supavonwong, P.; Saengsen, D.; Gongal, G.N.; Hemachudha, T. A longitudinal study of the prevalence of Nipah virus in Pteropus lylei bats in Thailand: evidence for seasonal preference in disease transmission. Vector Borne Zoonotic Dis. 2010, 10, 183-190.

72. Li, Y.; Wang, J.; Hickey, A.C.; Zhang, Y.; Li, Y.; Wu, Y.; Zhang, H.; Yuan, J.; Han, Z.; McEachern, J.; et al. Antibodies to Nipah or Nipah-like viruses in bats, China. Emerg. Infect. Dis. 2008, 14, 1974-1976.

73. Clayton, B.A.; Wang, L.F.; Marsh, G.A. Henipaviruses: an updated review focusing on the pteropid reservoir and features of transmission. Zoonoses Public Health 2013, 60, 69-83.

74. Chua, K.B.; Koh, C.L.; Hooi, P.S.; Wee, K.F.; Khong, J.H.; Chua, B.H.; Chan, Y.P.; Lim, M.E.; Lam, S.K. Isolation of Nipah virus from Malaysian Island flying-foxes. Microbes Infect. 2002, 4 , $145-151$.

75. Sohayati, A.R.; Hassan, L.; Sharifah, S.H.; Lazarus, K.; Zaini, C.M.; Epstein, J.H.; Shamsyul Naim, N.; Field, H.E.; Arshad, S.S.; Abdul Aziz, J.; et al. Evidence for Nipah virus recrudescence and serological patterns of captive Pteropus vampyrus. Epidemiol. Infect. 2011, $1-10$.

76. Bossart, K. Functional studies of host-specific ephrin-B ligands as Henipavirus receptors. Virology 2008, 372, 357-371.

77. Negrete, O.A.; Chu, D.; Aguilar, H.C.; Lee, B. Single amino acid changes in the nipah and hendra virus attachment glycoproteins distinguish EphrinB2 from EphrinB3 usage. J. Virol. 2007, 81, 10804-10814.

78. Field, H.; Young, P.; Yob, J.M.; Mills, J.; Hall, L.; Mackenzie, J. The natural history of Hendra and Nipah viruses. Microbes Infect. 2001, 3, 307-314.

79. Chua, K.B. Nipah virus outbreak in Malaysia. J. Clin. Virol. 2003, 26, 265-275.

80. Epstein, J.H.; Abdul Rahman, S.; Zambriski, J.A.; Halpin, K.; Meehan, G.; Jamaluddin, A.A.; Hassan, S.S.; Field, H.E.; Hyatt, A.D.; Daszak, P. Feral cats and risk for Nipah virus transmission. Emerg. Infect. Dis. 2006, 12, 1178-1179.

81. Mills, J.N.; Alim, A.N. M.; Bunning, M.L.; Lee, O.B.; Wagoner, K.D.; Amman, B.R.; Stockton, P.C.; Ksiazek, T.G. Nipah virus infection in dogs, Malaysia, 1999. Emerg. Infect. Dis. 2009, 15, 950-952.

82. Anonymous Hendra virus, equine - Australia (21): (QL) canine. ProMed Mail 2011, Archive Number: 20110802.2324. Available online at: http://www.promedmail.org/ (access on 4 April 2013).

83. Hayman, D.T.S.; Wang, L.-F.; Barr, J.; Baker, K.S.; Suu-Ire, R.; Broder, C.C.; Cunningham, A.A.; Wood, J.L.N. Antibodies to henipavirus or henipa-like viruses in domestic pigs in ghana, west Africa. PLoS One 2011, 6, e25256.

84. Mathieu, C.; Pohl, C.; Szecsi, J.; Trajkovic-Bodennec, S.; Devergnas, S.; Raoul, H.; Cosset, F.-L.; Gerlier, D.; Wild, T.F.; Horvat, B. Nipah Virus uses leukocytes for efficient dissemination within a host. J. Virol. 2011, 18, 7863-7881 
85. Stachowiak, B.; Weingartl, H.M. Nipah virus infects specific subsets of porcine peripheral blood mononuclear cells. PLoS One 2012, 7, e30855.

86. Field, H.; Schaaf, K.; Kung, N.; Simon, C.; Waltisbuhl, D.; Hobert, H.; Moore, F.; Middleton, D.; Crook, A.; Smith, G.; Daniels, P.; et al. Hendra virus outbreak with novel clinical features, Australia. Emerg. Infect. Dis. 2010, 16, 338-340.

87. Westbury, H.A. Hendra virus disease in horses. Rev. Off. Int. Epizoot. 2000, 19, 151-159.

88. Parashar, U.D.; Sunn, L.M.; Ong, F.; Mounts, A.W.; Arif, M.T.; Ksiazek, T.G.; Kamaluddin, M.A.; Mustafa, A.N.; Kaur, H.; Ding, L.M.; et al. Case-control study of risk factors for human infection with a new zoonotic paramyxovirus, Nipah virus, during a 1998-1999 outbreak of severe encephalitis in Malaysia. J. Infect. Dis. 2000, 181, 1755-1759.

89. Munster, V.J.; Prescott, J.B.; Bushmaker, T.; Long, D.; Rosenke, R.; Thomas, T.; Scott, D.; Fischer, E.R.; Feldmann, H.; Wit, E. de Rapid Nipah virus entry into the central nervous system of hamsters via the olfactory route. Sci. Rep. 2012, 2, 736.

90. Lo, M.K.; Miller, D.; Aljofan, M.; Mungall, B.A.; Rollin, P.E.; Bellini, W.J.; Rota, P.A. Characterization of the antiviral and inflammatory responses against Nipah virus in endothelial cells and neurons. Virology 2010, 404, 78-88.

91. Torres-Velez, F.J.; Shieh, W.-J.; Rollin, P.E.; Morken, T.; Brown, C.; Ksiazek, T.G.; Zaki, S.R. Histopathologic and immunohistochemical characterization of Nipah virus infection in the guinea pig. Vet. Pathol 2008, 45, 576-585.

92. Blackman, M.A.; Woodland, D.L. The narrowing of the CD8 T cell repertoire in old age. Curr. Opin. Immunol. 2011, 23, 537-542.

93. Frasca, D.; Blomberg, B.B. Aging impairs murine B cell differentiation and function in primary and secondary lymphoid tissues. Aging Dis. 2011, 2, 361-373.

94. Kovacs, E.J.; Palmer, J.L.; Fortin, C.F.; Fülöp, T., Jr; Goldstein, D.R.; Linton, P.-J. Aging and innate immunity in the mouse: impact of intrinsic and extrinsic factors. Trends Immunol. 2009, 30, 319-324.

95. Müller, U.; Steinhoff, U.; Reis, L.F.; Hemmi, S.; Pavlovic, J.; Zinkernagel, R.M.; Aguet, M. Functional role of type I and type II interferons in antiviral defense. Science 1994, 264, 1918-1921.

(C) 2013 by the authors; licensee MDPI, Basel, Switzerland. This article is an open access article distributed under the terms and conditions of the Creative Commons Attribution license (http://creativecommons.org/licenses/by/3.0/). 